\title{
RESEARCH PRIORITIES AND FUTURE DIRECTIONS IN CONSERVATION OF WILD ORCHIDS IN SRI LANKA: A REVIEW
}

\author{
J. Dananjaya Kottawa-Arachchi1 ${ }^{1, *}$, R. Samantha Gunasekara ${ }^{2}$ \\ ${ }^{1}$ Tea Research Institute of Sri Lanka, Sri Lanka \\ ${ }^{2}$ Lanka Nature Conservationists, Sri Lanka \\ *e-mail:jeevan1188@yahoo.com,jeevank@tri.lk
}

Received: 24.03.2020. Revised: 22.05.2020. Accepted: 29.05.2020.

\begin{abstract}
Together with Western Ghats, Sri Lanka is a biodiversity hotspot amongst the 35 regions known worldwide. Considering the Sri Lankan orchids, $70.6 \%$ of the orchid species, including $84 \%$ of the endemics, are categorised as threatened. The distribution of the family Orchidaceae is mostly correlated with the distribution pattern of the main bioclimatic zones which is governed by the amount and intensity of rainfall and altitude. Habitat deterioration and degradation, clearing of vegetation, intentional forest fires and spread of invasive alien species are significant threats to native species. Illegally collection and exporting of indigenous species has been another alarming issue in the past decades. Protection of native species, increased public awareness, enforcement of legislation and introduction of new propagation techniques would certainly bring a beneficial effect to the native orchid flora. Conduct awareness programs, strengthen existing laws, and reviewing the legal framework related to the native orchid flora could be vital for future conservation. Apart from the identification of new species and their distribution, future research on understanding soil chemical and physical parameters of terrestrial habitats, plant association of terrestrial orchids, phenology patterns and interactions of pollinators, associations with mycorrhiza, effect of invasive alien species and impact of climate change are highlighted.
\end{abstract}

Key words: awareness, biodiversity conservation, climate change, illegal exploitation, threatened species

\section{Introduction}

The family Orchidaceae is one of the largest flowering plant families in the world, comprising about $25000-30000$ species, and they account for approximately $8 \%$ of angiosperm species diversity (Chase et al., 2015). The distribution and abundance of orchids vary between continents and within regions, following hotspot of species richness, except in the Polar Regions (Myers et al., 2000). However, their distribution is not uniform, but skewed markedly towards the tropics (Cribb et al., 2003). The highest epiphytic and terrestrial species diversity is recorded in the tropical areas, particularly in rainforests and associated ecosystems in the Andes of South America, on Madagascar, Sumatra and Borneo and in Indo-China.

An enormous literature has emphasised that the future of orchid population is threatened and many species will face the extinction from wild habitats due to anthropogenic activities. Fragmentation of habitats, indiscriminate collection, habitat destruction, intentional wild fires, pollinator decline will result in the drastic loss of orchid populations (Fay, 2018). In Asia, due to a compound pressure on natural resources and the environment pollution associated with rapid urbanisation, industrialisation and economic development, a significant loss will be predicted for several wild species.

South Asia, including the Indian sub-continent, is considered as one of the mega biodiversity hotspot (Myers et al., 2000). These zones consist of tropical, sub-tropical and temperate climate with lush green and divers forest types. The Western Ghats comprises the major portion of the Western Ghats and Sri Lan$\mathrm{ka}$, one of 34 global biodiversity hotspots for conservation and one of the two on the Indian subcontinent (Gunawardene et al., 2007; Myers et al., 2000).

The aims of the present review are to summarise the literature on studies of wild orchids including publication information, location study, distribution pattern, ecosystem/habitat characteristics, anthropogenic effects and identifying the research gaps for promoting intense studies in future.

\section{Material and Methods}

Sri Lanka, with a total land area of $65610 \mathrm{~km}^{2}$, is a tropical island situated in the Indian Ocean. Sri Lanka's rich and unique biodiversity forms the basis for the country's natural heritage, and is a core feature of its cultural heritage and economic advancement. This high biodiversity seen in Sri Lanka can be attributed due to a wide variety of climatic, topographic and soil conditions on the island, resulted in a diverse array of aquatic and terrestrial habitats. Sri Lanka's biodiversity is significantly important both on a regional and global scale as it has the highest species density for flowering plants, amphibians, reptiles, and mammals in the Asian region (MOE, 2012). The majority of the endemic and threatened species are confined to the wet zone and especially to the montane ecosystem. The central highland complex of Sri Lanka is situated in the south central part of the island and is considered as a super biodiversity hotspot (UNESCO, 2010). More 
than $50 \%$ of the endemic vertebrates, $50 \%$ of the endemic flowering plants and more than $34 \%$ of the endemic trees, shrubs, and herbs are reported from these diverse montane rainforests and associated grassland areas (Gunawardene et al., 2007; MOE, 2012).

A thorough literature survey was conducted to extract available information regarding distribution, taxonomic status, threats, conservation and legal protection of wild orchids in Sri Lanka. The following information was extracted from available sources, both printed and digital platforms including printed books, local and international journal articles, conference proceedings, case studies and reports. The journals were selected for this review on the basis of their publications devoted to orchid related research. Among the selected journals, Lankesteriana is focusing exclusively on orchid systematics, ecology, evolution, and physiology. Phytotaxa is a scientific journal for publication on any aspect of systematic botany, new species, monographs, floras and revisions. Recently discovered Sri Lankan orchids have been published in Phytotaxa. Besides, research papers and reviews published in leading international journals such as Nature, Botanical Journal of the Linnean Society, Systematics and Biodiversity, Russian Journal of Ecology were referred to for the global scenario in orchid conservation. Resently, Khapugin (2020) used a similar method for a systematic global literature review on Orchidaceae taxa in Protected Areas. Further, abstracts and proceedings of local and international conferenses have been used to include distribution and conservation data of Sri Lankan orchids in this review.

In addition to the personal experience of the second author as Customs Officer, government acts were referred to extract the legal coverage of native species. Personal communication with orchid specialists and data gathered during several field visits to various part of the country by the authors are also included in this review to explain distribution patterns and anthropogenic effects.

The National Red List 2012 of Sri Lanka was referred to for emphasising the threatened status of native species. Recently published local and international research articles have been referred to for identifying reseach gaps and the future direction of orchid reseach in Sri Lanka.

\section{Results and Discussion Historical contributions to the Orchidaceae of Sri Lanka}

Several pioneers of relevant works have cited numerous records from Sri Lanka. Among these species, orchids form an interesting group. Fernando \& Ormerod (2008) have reviewed the contributions to the discoveries of new species in the national orchid flora by the past botanists and taxonomists. The botanist Paul Hermann (1646-1695) was the first botanist who made a collection of plants from Sri Lanka and made an impressive collection of dried plants and drawings. His collection included two orchids, Zeuxine strateumatica (L.) Schltr. and Peristylus cubitalis (L.) Kraenzl., the very first Sri Lankan orchids made known to the world (Fernando \& Ormerod, 2008). In addition, Konig (1728-1785) made collections of Sri Lankan native orchids and cited several specimens with their local names.

During the English colonial period, botanical gardens were established in Sri Lanka and a large number of herbarium collections were made by various botanists. Alexander Moon, James Macrae, Colonel Walker and his wife collected many orchid specimens from different parts of the country. The botanist George Gardener (1812-1849) and the naturalist George H.K. Thwaites (1812-1882) contributed to the botanical studies including native orchids immensely. The Handbook to the Flora of Ceylon which is recognised as a model for a tropical flora has been produced by Henry Trimen (1843-1896) and the volume containing Orchidaceae was completed by Joseph D. Hooker (18171911). A revision of the entire flora was initiated in 1968 and Martin A. Jayaweera (1912-1982) contributed to the revision of Orchidaceae. Fernando \& Ormerod (2008) published an updated checklist using recent information of the orchids of Sri Lanka. They attempted to solve some nomenclatural problems, species ambiguity, recent distribution records and find out current endemic species. Ariyarathne et al. (2017) recorded 78 wild orchids including 23 endemic species from 49 genera. They are dispersed within and outside the conservation areas including few unexplored/undocumented regions in the country.

\section{Present status of wild orchids}

The family Orchidaceae is among the largest flowering plant family in Sri Lanka (Fernando, 2012). According to the Red Data List of Sri Lanka (MOE, 2012), the wild orchid diversity is represented by 189 known species, belonging to 78 genera, including 55 endemic species. Furthermore, these numbers are continuously changing, as a result of taxonomic studies and recent discoveries of new species. Recent information indicates that 194 orchid species have been recorded 
in Sri Lanka till to date, but this number is still growing due to new findings.

Orchidaceae is currently facing exceptional risks of extinction, and despite conservation efforts, numerous orchid populations continue to decline (Barman $\&$ Devadas, 2013). More than any other plant family, Orchidaceae has a high proportion of threatened genera with mostly containing threatened species (Swarts \& Dixon, 2009). Considering the Sri Lankan orchids, $70.6 \%$ of the orchid species including $84 \%$ of the endemics are categorised as threatened, of which $9 \%$ of the species are Critically Endangered (CR), 29\% are Endangered (EN) and 31\% of species are Vulnerable (VU) (Fig. 1). Further, 2\% of the species are Critically Endangered Possibly Extinct (CR(PE)), 12\% are Near Threatened (NT) (MOE, 2012).

Factors determining distribution and abundance

The distribution and abundance of orchid populations depends on a suite of biological and ecological factors, including pollinator specialisation, seed production and dispersal, limited germination rates, viability of mycorrhizal fungi (Otero \& Flanagan, 2006) and appropriate environmental conditions (McCormick \& Jacquemyn, 2014). The symbiotic relationship between orchid and mycorrhizal fungi is considered as one of the vital biotic factor for seed germination, seedling growth and surviving in the natural habitats (Rasmussen \& Rasmussen, 2009).

The rising of global temperature due to climate change effect is invariably correlated with the abiotic factors which determine the orchid populations in the tropical region (Barman \& Devadas, 2013). Besides, temperature, altitude, and soil $\mathrm{pH}$ are the main factors affecting the distribution and abundance of terrestrial orchid species in grasslands and wetlands (Djordjević et al., 2016).

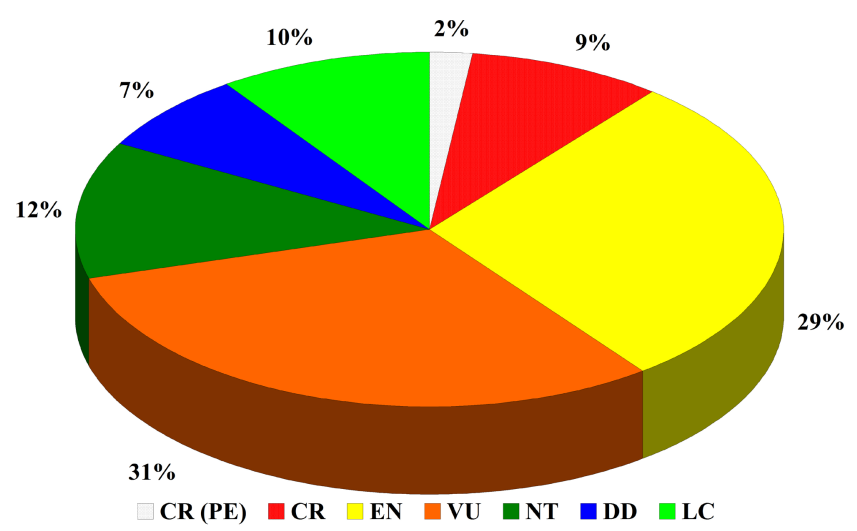

Fig. 1. Summary of the Red List status of the family Orchidaceae in Sri Lanka. Designations: CR(PE) - Critically Endangered (Probably Extinct), CR - Critically Endangered, EN - Endangered, VU - Vulnerable, NT - Near Threatened, DD - Data Deficient, LC - Least Concern.
Numerous studies have indicated the importance of certain vegetation types in determining the distribution and abundance of orchids (Landi et al., 2009; Djordjević et al., 2016; Khapugin et al., 2017). Grasslands, wet meadows, bogs, marshes and montane forests represent important ecosystems that host many orchid species. Furthermore, several studies have suggested that orchid enrichment is regulated by habitat size, altitude, climate, population size and sex structure (Acharya et al., 2011; Valuiskikh \& Teteryuk, 2013; Zhang et al., 2015; Khapugin et al., 2016).

The land profile of Sri Lanka varies from coastal areas through lowland hills to the central montane region. The distribution of Sri Lanka's different types of ecosystems depends largely on the spatial variation of rainfall and temperature on the island, as well as on its topographic variation and the spatial distribution and diversity of soils (MOE, 2010). Climatologically Sri Lanka is characterised by two seasons as wet and dry mainly based on the two monsoons. Areas with transitional weather condition is called the intermediate zone. The distribution of Orchidaceae is mostly correlated with the distribution pattern of the major bioclimatic zones (Table), which is governed by the amount and intensity of rainfall and altitude.

Arid and Dry zones. Dry mixed evergreen forest is the main vegetation type of this zone. These forests have a number of deciduous tree species. The lowest number of orchid species (about 15 species) has been recorded in this zone. Vanda tessellata (Roxb.) Hook. ex G.Don, Vanilla walkeriae Wight, Cymbidium aloifolium (L.) Sw. and Habenaria plantaginea Lindl., are the most dominant species.

Intermediate zone, dry grasslands (Patanas). This zone lies between the dry and wet zones. The recorded orchid diversity is much higher (about 28 species) than in the dry zone. A significant portion of this area is occupied by grasslands with sparsely distributed trees or «Savanna» type vegetation. Species like Rhynchostylis retusa (L.) Blume (Fig. $2 \mathrm{~K}$ ), Aerides ringens (Lindl.) C.E.C.Fisch. and Habenaria roxburghii Nicolson have been mainly recorded in the eastern part of the intermediate zone in grasslands. Due to a lack of tall trees, more terrestrial orchid species are found in the region of the Savana type vegetation. Ritigala, Monaragala, Kokagala and Doluwakanda are examples of isolated hills (inselbergs). These relatively small hills contain a rich variety of orchid diversity, a combination of dry zone/intermediate zone species and wet zone species. Several species which are commonly found in the lower montane zone like Disperis neilgherrensis Wight, Papilionanthe 
subulata (Willd.) Garay (Papilionanthe cylindrica (Lindl.) Seidenf.) are also recorded on the hilltop and the upper slopes of these isolated hills.

Lowland wet zone. This zone is dominated by tropical wet evergreen forests as high as $35-45 \mathrm{~m}$ at the canopy level with several dense strata. With the seasonally wet conditions, there is a rich diversity (about 80 species) of both epiphytes and ground orchids found in this zone. The diversity of mycohetrotrophic orchids is also high in this zone. New species like Dendrobium taprobanium Priyad., Atthan., Wijew., Aberathna, Peabotuwage \& Kumar (Priyadarshana et al., 2020), Pteroceras dalaputtuwa Atthan., Priyad., Wijew., Aberathna \& Kumar (Priyadarshana et al., 2019) and Gastrodia gunatillekeorum Bandara, Priyankara \& Kumar (Bandara et al., 2020) have been discovered in this zone.

Sub-montane zone. This zone represents an altitudinal belt of 1000-1500 $\mathrm{m}$ a.s.l. between the low wet zone and wet highlands. Tropical submontane evergreen forest is the most dominant natural vegetation in this area. This zone contains the highest orchid diversity (about 110 species) with numerous endemics in Sri Lanka. The newly identified Podochilus warnagalensis Wijew., Priyad., Arang., Atthan., Samar. \& Kumar (Wijewardana et al., 2016) and Oberonia meegaskumburae Priyad., Wijew. \& Kumar (Priyadarshana et al., 2017) are restricted to this zone.

Wet highlands. The area above $1500 \mathrm{~m}$ a.s.l. has been recognised as this zone. Relatively strong winds, elevated solar radiation and the influence of lower temperatures $\left(15-16^{\circ} \mathrm{C}\right)$ are other factors prevalent in this zone. Beside highland forests, the highland marshes are seen in the valleys and lower slopes of mountains associated with grasslands. In Sri Lanka, these unique wetland ecosystems are found only at a higher altitude. In this zone, orchids are very common (about 55 species) but have a lower diversity than in the lower montane zone (Fernando, 2012).
The distribution and abundance of terrestrial species depend on their habitat characteristics such as soil physical and chemical parameters, and associated plant species (Bowles et al., 2005; Tsiftsis et al., 2008; Djordjević et al., 2016; Kottawa-Arachchi et al., 2020). The epiphytic orchids have complex and critical relationships with some other species in their habitat, such as host plants, mycorrhizal association and flower adaptations for the attraction of specific pollinators. Although, Sri Lankan orchids show a vast diversity in distribution and dispersing in all the possible habitats, the majority of the threatened and endemic species are confined to the sub-montane zone with a limited distribution. The possible reasons for the high orchid diversity in the lower montane zone are the frequent mist, no dry period and cooler conditions in the forest (Ashton, 2003).

Frequently cloudy and misty conditions with reduced light in the montane zone is required for the growing of shade loving species such as Gastrodia zeylanica Schltr. and Bulbophyllum petiolare Thwaites (Fernando et al., 2003). Some terrestrial species, such as Ipsea speciosa Lindl. (Fig. 2B) and Satyrium nepalense D.Don, are recorded in wet grasslands in the central highland (Kottawa-Arachchi et al., 2020) whereas Rhynchostylis retusa and Habenaria roxburghii are restricted to savannah type dry grasslands in the Eastern Intermediate zone (Fernando, 2013). Several Sri Lankan orchid species have an unusually fragmented distribution pattern restricted to a few isolated hill tops. Thrixspermum pugionifolium (Hook.f.) Schltr., Taprobanea spathulata (L.) Christenson and Phalaenopsis mysorensis C.J.Saldanha are examples of species usually found on isolated hills in dry and two intermediate zones (Fernando et al., 2008; Fernando, 2013). Vanda tessellata, an epiphytic species, has a very interesting feature in a wide range of floral variations (Fig. 2A, Fig. $2 \mathrm{~J})$, which is distributed through the dry zone and intermediate zone margins (Gunasekara, 2016).

Table. Key bioclimatic zones of Sri Lanka

\begin{tabular}{|l|l|}
\hline \multicolumn{1}{|c|}{ Bioclimatic zone } & \multicolumn{1}{|c|}{ Key climatic and biological features } \\
\hline Arid zone & $\begin{array}{l}\text { Tropical thorn scrub with isolated trees. Altitude 0-100 m a.s.l. Annual rainfall less than 1250 mm } \\
\text { (mainly from October - January). More than five dry months. }\end{array}$ \\
\hline Dry zone & $\begin{array}{l}\text { Dry mixed evergreen forest. Altitude 0-500 m a.s.1. Annual rainfall 1250-1900 mm (mainly October - } \\
\text { January), 4-5 dry months. }\end{array}$ \\
\hline Intermediate zone & Moist evergreen forest. Altitude 500-1000 m a.s.l. Annual rainfall 1900-2500 mm. Less than three dry months. \\
\hline Lowland wet zone & $\begin{array}{l}\text { Tropical (lowland) wet evergreen forest. Altitude 0-1000 m a.s.l. Annual rainfall 2500-5000 mm. } \\
\text { No dry months. }\end{array}$ \\
\hline Sub-montane zone & Sub-montane evergreen forest. Altitude 1000-1500 m a.s.l. Annual rainfall 2500-5000 mm. No dry months. \\
\hline Wet highlands & Montane evergreen forest. Altitude 1500-2500 m a.s.l. Annual rainfall 2500-5000 mm. No dry months. \\
\hline Note: a.s.l. - above sea level; source: MOFE (1999).
\end{tabular}



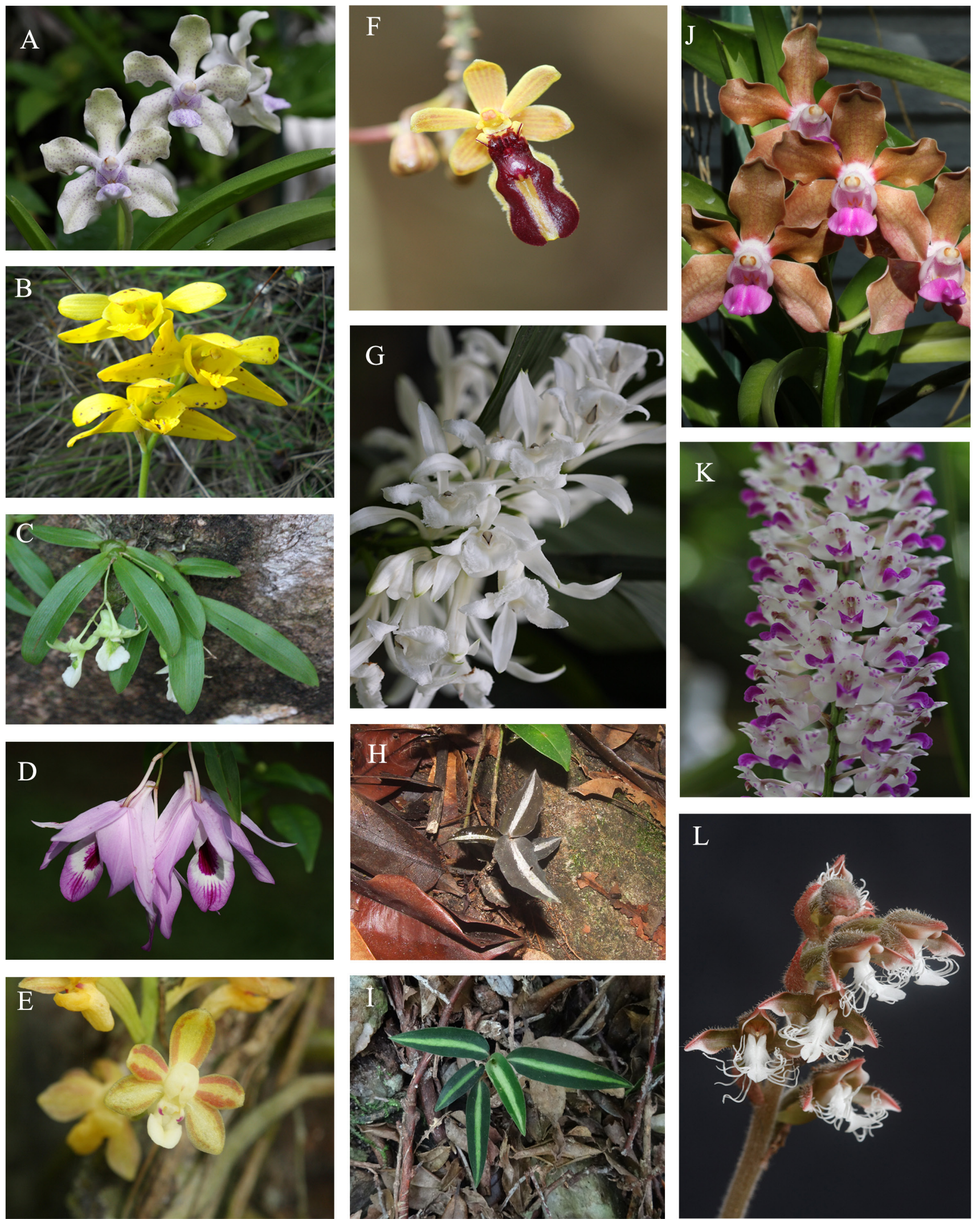

Fig. 2. A - Vanda tessellata, a rare white colour variant found in intermediate to dry zone; B - Ipsea speciosa found in wet grasslands, central highlands; C - Dendrobium taprobanium found in lowland-wet zone; D - Dendrobium maccarthiae found in lowland wet zone; E - Cleisostoma tenuifolium found in lowland wet zone; F - Cottonia peduncularis found in lowland wet to intermediate zone; G - Corymborkis veratrifolia found in lowland wet to submontane zone; H - Zeuxine reginasilvae found in lowland wet zone; I - Zeuxine regia found in submontane zone; $\mathrm{J}$ - Vanda tessellata, a rare reddish-brown colour variant with pink labellum found in intermediate to dry zone; $\mathrm{K}$ Rhynchostylis retusa, a rare reddish purple colour variant found in intermediate zone; $\mathrm{L}$-Anoectochilus regalis found in lowland wet to submontane zone. 


\section{Threats and conservation}

Habitat deterioration and degradation, clearing of vegetation, intentional forest fires and the spread of invasive alien species are significant threats to highland grasslands and wetlands in Sri Lanka (Kotagama \& Bambaradeniya, 2006; MOE, 2010). In the montane and sub-montane areas, forests and grasslands are cleared for vegetable cultivation, this being the main agriculture-based threat. The excessive use of agro chemicals is believed to have a considerable impact on the survival of the orchid species. Besides, forest felling for firewood, encroachments and illegal settlements, intentional forest fire and garbage dumping are the main habitat related threats to native orchid survival (Fernando, 2012).

\section{Habitat deterioration}

Orchids are susceptible to habitat fragmentation due to their unique reproductive strategies, specific interactions with symbionts, host plant specificity and often specific habitat requirements (Kolanowska et al., 2017). With the increasing demand for agricultural products, abandoned lands, especially grasslands, are vulnerable to encroachment. Unfortunately, these encroachments are established permanently, leading to a significant loss of the natural vegetation (Wijesundara, 2012; Kottawa-Arachchi, 2017). Furthermore, fragmentation of habitats also has a detrimental effect on small populations, especially of rare and threatened species.

Fire disturbance is serious when soil is overheated and most of the grasslands on the Western and Eastern slopes of the Central Highland set fire, during the dry periods, especially January - April and July - August, respectively. Repeated incidents of intentional fires might be deleterious and could also negatively impact existing protocorms, seedlings, and non-flowering mature plants, reproductive parts including flowers, capsules, seeds and possibly even alter the mycorrhizal community, hence lead to the loss of terrestrial orchids such as Arundina graminifolia (D.Don) Hochr., Ipsea speciosa and Satyrium nepalense (Fernando, 2012; Kottawa-Arachchi et al., 2020).

\section{Pollution}

Environmental pollution including air, water and soil has a detrimental effect on the species (MOE, 2012; Mohotti \& Amarasena, 2013). There are many publications on excessive use and the human, environmental effect of agrochemicals in Sri Lanka (Pethiyagoda, 1994; Jayasumana et al., 2014). Several terrestrial species, such as Arundina graminifolia, Ipsea speciosa and Satyrium nepalense, have been record- ed in highland grasslands adjacent to tea plantations and agricultural fields (Teoh, 2005, 2016; KottawaArachchi et al., 2020). Therefore, the agro-chemicals and other pollutants will be a potential threat for the survival of terrestrial orchids in the central highlands of Sri Lanka (Fernando et al., 2003).

Bio-indicators can include natural biological processes, animals, plants, or communities of organisms that can be used to determine the quality of the environment and how it changes over time. Orchid species are usually considered as a bio indicator of health and biodiversity of the natural forest due to their high sensitivity to shifts of the microclimate (Shashidhar \& Kumar, 2009; Youssef et al., 2019). Orchids depend on specific fungi for nourishment during seed germination, and it is vital that those fungi are not destroyed by fungicides and other biocides polluting the environment. Another important factor controlling orchid populations is the availability of pollinators. Akhalkatsi et al. (2014) have reported that anthropogenic activities displayed negative impacts on both the diversity of orchid species and their pollinator bees.

\section{Spreading of invasive alien species}

Invasive alien plants have been widely recognised to exert a significant negative impact including superior competitors for limited resources in comparison with their native counterparts, novel chemical compounds, novel biotic interactions on native species, communities and ecosystems (Vilà et al., 2011). Numerous studies have shown that invasive plant species impose greater effects than dominant native species on the growth and reproduction of native residents (Vilà et al., 2011; Kuebbing \& Nunez, 2016).

The spread of invasive species has created a considerable impact for many orchid-rich habitats in Sri Lanka. The invasive evergreen tree species Clusia rosea Jacq. has been proven to be a highly effective invader, threatening the lower montane ecosystem (Fernando, 2012). This species is rapidly spreading in wet grasslands and natural forests in Kandy and Nuwara Eliya districts. Among invasive species, the Neotropical shrub Austroeupatorium inulifolium (Kunth) R.M.King \& H.Rob. and Megathyrsus maximus (Jacq.) B.K.Simon \& S.W.L.Jacobs have been recorded in both wet and dry grasslands on the Western and Eastern slope of the central highland. Besides, populations of the rapidly growing invasive species Ageratina riparia (Regel) R.M.King \& H.Rob. and Mimosa invisa Mart. ex Colla have been recorded from several sub-montane grasslands as accompanying flora (Kottawa-Arachchi, 2017). The presence 
of invasive species has a negative effect on native plants, indicating that invasive species may displace native species like the terrestrial orchids Ipsea speciosa and Satyrium nepalense. The present growth of the above mentioned invasive species has indicated the future shrinkage of populations of terrestrial orchids (Kottawa-Arachchi et al., 2020).

\section{Direct exploitation / illegal collection}

Indigenous orchid species are subjected to local and international trade (Gunasekara \& Wijesundara, 2008; Gunasekara et al., 2019a). Illegal exporting of indigenous species, such as Acampe praemorsa (Roxb.) Blatt. \& McCann, Bulbophyllum elegans Gardner ex Thwaites, Cymbidium aloifolium, Dendrobium spp., Eria spp., Malaxis spp., Polystachya concreta (Jacq.) Garay \& H.R.Sweet, Sirhookera spp., Taprobanea spathulata, Thrixspermum pulchellum (Thwaites) Schltr., Vanda tessellata, and V. testacea (Lindl.) Rchb.f., have been detected in the past two decades (Gunasekara \& Wijesundara, 2008; Gunasekara et al., 2019a,b). There were detections when attempts to smuggle out specimens of native species like Acampe praemorsa var. longepedunculata (Trimen) Govaerts (Acampe rigida (Buch.-Ham. ex Sm.) P.F.Hunt), Adrorhizon purpurascens (Thwaites) Hook.f., Angraecum zeylanicum Lindl., Aerangis hologlottis (Schltr.) Schltr., Bulbophyllum elliae Rchb.f., B. thwaitesii Rchb.f., B. wightii Rchb.f., Cleisostoma tenuifolium (L.) Garay (Fig. 2E), Coelogyne odoratissima Lindl., C. zeylanica (Hook.f.) Aver., Cymbidium bicolor Lindl., Diploprora championii (Lindl.) Hook.f., Eria bicolor (Lindl.) Kuntze, E. lindleyi Thwaites, E. tricolor (Thwaites) Kuntze, Luisia tenuifolia Blume, Oberonia wightiana Lindl., Papilionanthe subulata (Willd.) Garay, Pholidota imbricata Hook., Podochilus saxatilis Lindl., Polystachya concreta (Jacq.) Garay \& H.R.Sweet, Robiquetia brevifolia (Lindl.) Garay, R. rosea (Lindl.) Garay, Seidenfadeniella filiformis (Rchb.f.) Christenson \& Ormerod, Thrixspermum walkeri Seidenf. \& Ormerod, and Vanda tessellata, which had been collected from wild habitats (Gunasekara et al., 2019a).

The taxa of Anoectochilus regalis Blume, Acampe praemorsa, A. praemorsa var. longepedunculata, Cymbidium aloifolium, Eulophia epidendraea (J.Koenig ex Retz.) C.E.C.Fisch., Eulophia graminea Lindl., Phaius wallichii Lindl., Rhynchostylis retusa, Taprobanea spathulata, and Vanda tessellata are in the illegal local trade. It has been observed that Acampe praemorsa (incl. A. praemorsa var. longepedunculata) were used to sell to the common public under the guise of Vanda tessellata (Gunasekara et al., 2019b). Vanda tessellata is the most heavily traded indigenous orchid species within and from Sri Lanka (Gunasekara et al., 2019a).

According to the available literature, certain rare colour forms, such as white Dendrobium maccarthiae Thwaites, white Ipsea speciosa, white Rhynchostylis retusa, Vanda tessellata with white tepals and labellum, $V$. tessellata with canary yellow tepals with canary yellow labellum, have been extinct from Sri Lanka as a result of local and international trade (Gunasekara, 2016; Gunasekara et al., 2019a).

Besides, nature-based tourism is a popular form of tourism and is one of the few human activities permitted in many Protected Areas. For an important and charismatic group of plants such as orchids, naturebased tourism could contribute to species loss. Direct threats from tourism include collecting plants from the wild by tourists and by those providing tourism attractions, habitat clearance for tourism facilities and making foot paths (Cribb et al., 2003; Kelly et al., 2003). Furthermore, eco-tourism contributes to the spread of weeds and invasive species.

\section{Research gaps and research needs}

Taxonomic contra-version and new species

Sri Lanka is considered as a biodiversity hotspot, harbouring a high number of endemic plant species, and new species are being added continuously. The taxonomic identification of Sri Lankan orchids is mostly conducted by the researchers with the help of drawings and the specimen deposited in the Royal Botanic Garden, Peradeniya, Sri Lanka. The most recent systematic treatment of Sri Lankan Orchids was conducted by Arthur Jayaweera, who published a book with taxonomic details of all Sri Lankan orchids (Jayaweera, 1981). According to Fernando \& Ormerod (2008) some deviations from Jayaweera's treatment were identified. They pointed out such deviation as i) many name changes with reference to some global and regional generic treatments, ii) marked reduction of a number of Sri Lankan endemic species due to many regional findings and iii) increased number of total species by addition to many new species.

Descriptions of new orchid taxa should preferably include genetic as well as morphological studies. Many descriptions of new species now include molecular (DNA) analyses to demonstrate their necessity is an accepted basis for the description of new taxa (Chase et al., 2015). Recently described orchid species are also being published in studies in which DNA evidence for their distinctiveness is included (Su et al., 2014; Xu et al., 2014). Molecular taxonomy has generated more information, leading to dramatic changes in orchid taxonomy and classification. Some of the Sri 
Lankan taxa have been recently revised based on the specimens deposited in herbaria but molecular taxonomic studies are vital to discriminate new species and confirmation of possibly extinct species. Recently, several new species such as Podochilus warnagalensis, Oberonia meegaskumburae, Pteroceras dalaputtuwa, Dendrobium taprobanium, and Gastrodia gunatillekeorum have been identified based on morphological descriptions. Furthermore, molecular taxonomic and phylogenetic studies would be much helpful to resolve current taxonomic discrepancies.

\section{Habitat and ecological studies}

Most of the endangered orchid species show a limited distribution and some of them have not been recorded from the type localities recently. According to the Red Data List, published in 2012, four species have not been recorded for a considerable time from their possible habitat and categorised as possible extinct species. However, Pteroceras viridiflorum (Thwaites) Holttum, considered a «Critically Endangered Possibly Extinct» (CR(PE)) orchid, was also re-collected by Priyadarshana et al. (2019) after a gap of nearly 150 years, and with a record of a new colour form.

Besides, recently discovered new species are very much restricted to their type localities in a few square kilometres. Especially, the newly discovered Dendrobium taprobanium is only known from a single location whereas Pteroceras dalaputtuwa has been recorded in a small population comprising only 20 plants with an area occupancy of $2 \times 2 \mathrm{~km}$ (Priyadarshana et al., 2019). These species grow as an epiphyte or lithophyte on lichen- and moss-covered tree trunks or wet rocks and boulders, under $80-90 \%$ shade. Mostly, host trees belong to the family Dipterocarpaceae and Dilleniaceae. On the other hand, Podochilus warnagalensis grows on lichen and moss covered granite rocks and boulders in streams. The plants, loosely attached to the substrate, are exposed to almost 100\% sunlight (Wijewardana et al., 2016). These findings are highlighted to conduct proper ecological studies to find out the factors effecting the restricted distribution of threatened species. Furthermore, research on understanding soil chemical and physical parameters of terrestrial habitats, plant association of terrestrial orchids, phenology patterns and interactions of pollinators and associations with mycorrhizal species are needed.

\section{Effect of climate change}

The current and expected changes in the global climate are the major threat for biological diversity (Walther et al., 2002). Climate change impacts on environment lead to a reduction in the distribution and abundance of species, especially endemics, which may even result in their global extinction (Kottawa-Arachchi \& Wijeratne, 2017). Orchids are well adapted to their epiphytic habitats and share light, temperature, air, moisture and nutrients with other epiphytes in the forest canopy. The recent studies have confirmed that Orchidaceae is among the largest flowering plant family which is currently facing exceptional risks of extinction and numerous populations continue to decline. Because of the dependence on their host for C-supply, orchid mycorrhiza and all heterotrophic mycorrhizal groups will be immediately impacted through a loss of habitat and plant-hosts (Kolanowska et al., 2017). Although grasslands are considered as vulnerable to the climate change, the long term monitoring of adaptability of plant communities and reproductive biology which respond to extreme weather events is essential for understanding the future impact of climate change (Kottawa-Arachchi \& Wijeratne, 2017).

\section{Legal protection for native orchids}

Only six species of orchids were protected under the Fauna \& Flora Protection Ordinance (FFPO) (Anonymous, 1937), when an Amended Act expanded the protection for 39 species included in the schedule V (Anonymous, 1993) and the entire family Orchidaceae is protected under schedule VIII of the existing law (Anonymous, 2009). The FFPO provide further protection of orchids by protecting the host trees which bear orchid plants. As per the provisions of section 42 of the principal enactment no person can remove, uproot or destroy, or cause any damage or injury to any tree which bears epiphytic orchids. Section 45 of FFPO states the punishments for the violations as a fine not less than ten thousand rupees and not more than twenty thousand rupees or to imprisonment of either description for a term not less than two years and not exceeding five years or to both such a fine and imprisonment (Anonymous, 1937, 1993, 2009). The Convention on International Trade in Endangered Species of Wild Fauna and Flora (CITES) permit is required to import/export those listed species (Hinsley et al., 2018). According to the National Red Data Book (MOE, 2012) for threatened species, 160 of those species are threatened.

Furthermore, GIS mapping has high potential to categorise the grasslands especially away from the Protected Area with their present status. It also helps to take administrative decisions for future protection (Kottawa-Arachchi, 2017). Main institutes such as the Ministry of Environment (MOE), Department of Wildlife Conservation (DWLC), Forest Conservation Department (FCD), and Central Environmental Au- 
thority (CEA) should examine government policies, identify gaps, strengthen existing laws, and review the legal framework relating to the conservation of habitats and threatened species.

\section{Awareness}

At present, public awareness on wild orchids is not much adequate. Although legislative measures play an important role the most effective measure to conserve orchids, public awareness on native orchids would be much important for future conservation. Species with showy flowers and medicinal properties have been vulnerable to over-collection from the wild. Among them, Dendrobium maccarthiae, Phaius wallichii, Rhynchostylis retusa, and Vanda tessellata are threatened by plant breeders and flower enthusiasts. Flowers of certain species, such as Dendrobium maccarthiae (Fig. 2D), are used as special temple offerings in Sri Lanka (Hinsley et al., 2018).

Besides, certain species, such as Ipsea speciosa, Anoectochilus regalis (Fig. 2L), Cymbidium aloifolium, Eulophia epidendraea, E. graminea, Luisia tenuifolia, L. zeylanica Lindl., Podochilus saxatilis, $P$. malabaricus Wight, Rhynchostylis retusa, Habenaria crinifera Lindl., Vanda tessellata, Vanilla walkeriae, Zeuxine regia (Lindl.) Trimen (Fig. 2I), and Z. reginasilvae Ormerod (Fig. 2H) are used in indigenous medicine. Taxa, including Anoectochilus regalis, Acampe praemorsa, A. praemorsa var. longepedunculata, Cymbidium aloifolium, Eulophia epidendraea, E. graminea, Phaius wallichii, Rhynchostylis retusa, Taprobanea spathulata, and Vanda tessellata, are in the illegal local trade. Acampe praemorsa (incl. A. praemorsa var. longepedunculata) is being sold to the common public under the guise of Vanda tessellata.

Very little has been published on the biology/ life cycle and artificial propagation of native species. Kumari et al. (2006) reported the successful artificial propagation of Ipsea speciosa seeds under in vitro conditions suggesting that the seeds were germinable. Studies on mass propagation of medicinally valuable species would be an added advantage to reduce the illegal collection of native species from wild habitats.

\section{Conclusions}

Although Sri Lanka is rich in orchid diversity, the survival of native species is becoming alarmingly threatened, due to various anthropogenic activities. These activities are habitat deterioration and degradation, clearing of vegetation, intentional forest fires and illegal collection from the wild habitats. Studies on ecology and habitat complexity, phenology patterns, interactions of pollinators and effects of cli- mate change are the suggested future research areas. Conduct awareness programs, enforce existing laws that relates to the native orchid flora could be vital for future conservation. Furthermore, the national and international collaboration and co-operation between scientific researchers is important for future research.

\section{Acknowledgments}

We are grateful to Mr. Kushan Premarathna (Department of Agriculture, Seetha Eliya, Sri Lanka) for preparing Fig. 2 with all orchid photographs using Photoshop software. We would like to thank the anonymous reviewers for their constructive comments and feedback on earlier versions of this paper.

\section{References}

Acharya K.P., Vetaas O.R., Birks H.J.B. 2011. Orchid species richness along Himalayan elevational gradients. Journal of Biogeography 38(9): 1821-1833. DOI: 10.1111/j.13652699.2011.02511.x

Akhalkatsi M., Arabuli G., Lorenz R. 2014. Orchids as indicator species of forest disturbances on limestone quarry in Georgia (South Caucasus). Journal Europäischer Orchideen 46(1): 123-160.

Anonymous. 1937. Fauna and Flora Protection Ordinance, No. 02. Sri Lanka: Government Press. 46 p.

Anonymous. 1993. Fauna and Flora Protection Act (Amendment), No. 49. Sri Lanka: Government Press. 55 p.

Anonymous. 2009. Fauna and Flora Protection Act (Amendment), No. 22. Sri Lanka: Government Press. 80 p.

Ariyarathne W.A.M.P., Yakandawala D., Samuel R., Wijesundara S. 2017. Evaluating the occurrence and conservation statuses of Sri Lankan Orchids (Orchidaceae): Observations on newly recorded species and undocumented regions. Phytotaxa 308(1): 37-53. DOI: 10.11646/phytotaxa.308.1.3

Ashton P.S. 2003. Floristic zonation of tree communities on wet tropical mountains revisited. Perspectives in Plant Ecology, Evolution and Systematics 6(1-2): 87-104. DOI: 10.1078/1433-8319-00044

Bandara C., Priyankara T., Atthanagoda A.G., Lakkana T., Ediriweera S., Kumar P. 2020. Gastrodia gunatillekeorum (Gastrodieae, Epidendroideae, Orchidaceae), a new species from a lowland rainforest of Sri Lanka. Phytotaxa 436(1): 55-62. DOI: 10.11646/phytotaxa.436.1.5

Barman D., Devadas R. 2013. Climate change on orchid population and conservation strategies: A review. Journal of Crop and Weed 9(2): 1-12.

Bowles M., Zettler L., Bell T., Kelsey P. 2005. Relationships between soil characteristics, distribution and restoration potential of the federal threatened eastern prairie fringed orchid, Platanthera leucophaea (Nutt.) Lindl. American Midland Naturalist 154(2): 273-285. DOI: 10.1674/0003-0031(2005)154[0273:RBSCDA]2.0.CO;2

Chase M.W., Cameron K.M., Freudenstein J.V, Pridgeon A.M., Salazar G., van den Berg C., Schuiteman A. 2015. An updated classification of Orchidaceae. Botanical Journal of the Linnean Society 177(2): 151-174. DOI: 10.1111/boj.12234 
Cribb P. J., Kell S.P., Dixon K.W., Barrett R.L. 2003. Orchid conservation: a global perspective. In: Orchid Conservation. Kota Kinabalu, Sabah: Natural History Pub. P. 1-4.

Djordjević V., Tsiftsis S., Lakušić D., Jovanović S. 2016. Factors affecting the distribution and abundance of orchids in grasslands and herbaceous wetlands grasslands and herbaceous wetlands. Systematics and Biodiversity 14(4): 355-370. DOI: 10.1080/14772000.2016.1151468

Fay M.F. 2018. Orchid conservation: how can we meet the challenges in the twenty-first century? Botanical Studies 59(16): 16. DOI: 10.1186/s40529-018-0232-Z

Fernando M., Wijesundara S., Fernando S. 2003. Orchids of Sri Lanka. A conservationist's companion. A simplified guide to identification. Vol. 1: The protected orchids and selected similar species. Colombo: IUCN Sri Lanka. 147 p.

Fernando R.H.S. 2012. Present status of family Orchidaceous in Sri Lanka. In D.K. Weerakoon, S. Wijesundara (Eds.): The National Red List 2012 of Sri Lanka: Conservation Status of the Fauna and Flora. Colombo, Sri Lanka: Ministry of Environment. P. 200-204.

Fernando S.S. 2013. Distribution and habitat selection of threatened Orchids of Sri Lanka. In: $11^{\text {th }}$ Asia Pacific Orchid Conference in Okinawa, Japan. Okinawa, Japan. P. 103-108.

Fernando S.S., Ormerod P. 2008. An annotated checklist of the Orchids of Sri Lanka. Rheedea 18(1): 1-28.

Fernando S.S., Gunatilleke I.A.U.N., Gunasekara S., Gunatilleke C.V.S., Abewardana U.T.I. 2008. Phalaenopsis mysorensis Saldanha (Orchidaceae): Note on distribution and ecology. Ceylon Journal of Science (Biological Sciences) 37(2): 163-166. DOI: 10.4038/cjsbs.v37i2.503

Gunasekara R.S. 2016. Flower polymorphism of naturally occurring Vanda tessellata in Sri Lanka. In: Proceedings of the Wayamba University International Conference. Sri Lanka. P. 242.

Gunasekara R.S., Wijesundara D.S.A. 2008. Investigation of the relationship between floral diversity and the reproductive success of Vanda tessellata (Roxb.) Hook. Colombo, Sri Lanka: Department of Wild Life Conservation.

Gunasekara R.S., Yakandawala K., Jayakody S., Wijesundara D.S.A. 2019a. Orchid trade in Sri Lanka with special reference to Vanda tessellata. In: International Symposium of Global Dialogue on Wildlife Trafficking. Sri Lanka: University of Colombo. P. 4.

Gunasekara R.S., Yakandawala K., Jayakody S., Wijesundara D.S.A. 2019b. A case study on Vanda tessellata (Roxb) Hook. ex G. Don trade in Sri Lanka. In: International Scientific Symposium of Association for Tropical Biology and Conservation (ATBC): AsiaPacific Chapter. Sri Lanka. P. 163.

Gunawardene N.R., Daniels D.A., Gunatilleke I.A.U.N., Gunatilleke C.V.S., Karunakaran P.V., Nayak G.K., Vasanthy G. 2007. A brief overview of the Western Ghats-Sri Lanka biodiversity hotspot. Current Science 93(11): 1567-1572.

Hinsley A., De Boer H.J., Fay M.F., Gale S.W., Gardiner L.M., Gunasekara R.S., Kumar P., Masters S., Metusala D., Roberts D.L., Veldman S., Wong S., Phelps J. 2018. A Review of the Trade in Orchids and Its Implications for Conservation. Botanical Journal of the Linnean Society 186(4): 435-55. DOI:10.1093/botlinnean/box083
Jayasumana C., Gunatilake S., Senanayake P. 2014. Glyphosate, hard water and nephrotoxic metals: are they the culprits behind the epidemic of chronic kidney disease of unknown etiology in Sri Lanka? International Journal of Environmental Research and Public Health 11(2): 2125-2147. DOI: 10.3390/ijerph110202125

Jayaweera D.M.A. 1981. Orchidaceae. In: M.D. Dassanayake, F.R. Fosberg (Eds.): A Revised handbook to the flora of Ceylon. Vol. 2. New Delhi, India: Amerind Publication Co. Pvt. Ltd. P. 4-387.

Kelly C., Pickering C.M., Buckley R.C. 2003. Impacts of tourism on threatened plant taxa and communities in Australia. Ecological Restoration and Management 4(1): 37-44. DOI: 10.1046/j.1442-8903.2003.00136.x

Khapugin A.A. 2020. A global systematic review on orchid data in protected areas. Nature Conservation Research 5(Suppl.1): 19-33. DOI: 10.24189/ncr.2020.019

Khapugin A.A., Chugunov G.G., Vargot E.V. 2017. Cypripedium calceolus ( Orchidaceae ) in Central Russia : a case study for its populations in two protected areas in the Republic of Mordovia (Russia). Lankesteriana 17(3): 417-431. DOI: 10.15517/lank.v17i3.31577

Khapugin A.A., Silaeva T.B., Semchuk A.A., Kunaeva E.N. 2016. Populations of Orchis militaris L ., Epipactis palustris ( L.) Crantz and Malaxis monophyllos ( L.) Sw. in the Republic of Mordovia ( Central Russia ). Biodiversity Research and Conservation 42: 33-40. DOI: 10.1515/biorc-2016-0012

Kolanowska M., Kras M., Lipińska M., Mystkowska K., Szlachetko D.L., Naczk A.M. 2017. Global warming not so harmful for all plants-response of holomycotrophic orchid species for the future climate change. Scientific Reports 7(1): 12704. DOI: 10.1038/s41598-017-13088-7

Kotagama S.W., Bambaradeniya C.N.B. 2006. An overview of the wetlands of Sri Lanka and their conservation significance. In: National Wetland Directory of Sri Lanka. Colombo, Sri Lanka: IUCN Sri Lanka and Central Environmental Authority. P. 7-16.

Kottawa-Arachchi J.D. 2017. Biodiversity in central highland wetlands, a world heritage site in Sri Lanka. In: A.K.B. Prusty, R. Chandra, P.A. Azeez (Eds.): Wetland Science: Perspectives From South Asia. New Delhi: Springer. P. 67-85. DOI: 10.1007/978-81-322-3715-0_4

Kottawa-Arachchi J.D., Liyanage M.G.S., Karunarathne H.K.B.M.I., Abeyweera N.H.A.S., Kulasinghe B.Y.M., Kahawandala K.R.S.C.B. 2020. The endangered Daffodil Orchid Ipsea speciosa (L.) (Orchidaceae): Population status in unprotected areas in the Central Highlands, Sri Lanka. Lankesteriana 20(1): 79-90. DOI: 10.15517/lank.v20i1.41434

Kottawa-Arachchi J.D., Wijeratne M.A. 2017. Climate change impacts on biodiversity and ecosystems in Sri Lanka: a review. Nature Conservation Research 2(3): 2-22. DOI: 10.24189/ncr.2017.042

Kuebbing S.E., Nunez M.A. 2016. Invasive non-native plants have a greater effect on neighbouring natives than other non-natives. Nature Plants 2: 16134. DOI: 10.1038/ nplants.2016.134

Kumari D., Fernando K., Wijesundara S. 2006. Mass propagation and conservation of Daffodil Orchid (Ipsea spe- 
ciosa): An endangered endemic orchid. In: Proceedings of the Third Academic Sessions. Sri Lanka: University of Ruhuna. P. 44-49.

Landi M., Frignani F., Lazzeri C., Angiolini C. 2009. Abundance of Orchids on calcareous grasslands in relation to community species, environmental, and vegetational conditions. Russian Journal of Ecology 40(7): 486-494. DOI: 10.1134/S1067413609070066

McCormick M.K., Jacquemyn H. 2014. What constrains the distribution of orchid populations? New Phytologist 202(2): 392-400. DOI: 10.1111/nph.12639

MOE. 2010. Biodiversity and ecosystem services: Sector vulnerability profile. In Strengthening Capacity for Climate Change Adaptation: ADB TA 7326 (SRI). Sri Lanka: Ministry of Environment; Climate Change Secretariat. P. 1-90.

MOE. 2012. The National Red List 2012 of Sri Lanka; Conservation status of the fauna and flora. Colombo, Sri Lanka: Ministry of Environment. $451 \mathrm{p}$.

MOFE. 1999. Biodiversity Conservation in Sri Lanka: A Framework for Action. Colombo, Sri Lanka: Ministry of Forestry and Environment. P. 1-126.

Mohotti K.M., Amarasena P.G.D.S. 2013. Microbial activity different tea soils in Sri Lanka as affected by soil pesticides. In: Proceedings of the National Symposium on Soil Biodiversity. Sri Lanka: Ministry of Environment and Renewable Energy. P. 167-170.

Myers N., Mittermeier R.A., Mittermeier C.G., da Fonseca G.A.B., Kent J. 2000. Biodiversity hotspots for conservation priorities. Nature 403(6772): 853-858. DOI: $10.1038 / 35002501$

Otero J.T., Flanagan N.S. 2006. Orchid diversity - beyond deception. Trends in Ecology and Evolution 21(2): 64 65. DOI: $10.1016 /$ j.tree.2005.11.016

Pethiyagoda R. 1994. Threats to the indigenous freshwater fishes of Sri Lanka and remarks on their conservation. Hydrobiologia 285(1-3): 189-201. DOI: 10.1007/BF00005666

Priyadarshana T.S., Wijewardhane I.H., Atthanagoda A.G., Arangala N.S., Jayasooriya A., Kumar P. 2017. Oberonia meegaskumburae (Orchidaceae: Epidendroideae: Malaxideae), a new species from Sri Lanka. Phytotaxa 302(3): 259-265. DOI: 10.11646/phytotaxa.302.3.5

Priyadarshana T.S., Atthanagoda A.G., Wijewardhane I.H., Siriweera K.S., Abeyrathna N., Kumar P. 2019. Pteroceras dalaputtuwa (Orchidaceae: Epidendroideae: Vandeae: Aeridinae), a new species from Sri Lanka and re-collection of Pteroceras viridiflorum after 150 years. Phytotaxa 399(1): 65-76. DOI: 10.11646/phytotaxa.399.1.7

Priyadarshana T.S., Atthanagoda A.G., Wijewardhane I.H., Aberathna N., Peabotuwage I., Kumar P. 2020. Dendrobium taprobanium (Orchidaceae): a new species from Sri Lanka with taxonomic notes on some species of the genus. Phytotaxa 432(1): 81-94. DOI: 10.11646/phytotaxa.432.1.7

Rasmussen H.N., Rasmussen F.N. 2009. Orchid mycorrhiza: Implications of a mycophagous life style. Oikos 118(3): 334-345. DOI: 10.1111/j.1600-0706.2008.17116.x

Shashidhar K.S., Kumar A.N.A. 2009. Effect of climate change on orchids and their conservation strategies. The Indian Forester 8: 1039-1049.
Su Y.Y., Meng Y., Shi Y., Tang G.D., Liu Z.J. 2014. Liparis funingensis (Orchidaceae; Epidendroideae; Malaxidae), a new species from Yunnan, China: Evidence from morphology and DNA. Phytotaxa 166(1): 8593. DOI: $10.11646 /$ phytotaxa.166.1.6

Swarts N.D., Dixon K.W. 2009. Terrestrial orchid conservation in the age of extinction. Annals of Botany 104(3): 543-556. DOI: 10.1093/aob/mcp025

Teoh E.S. 2005. Sympodial orchids. In: Orchids of Asia. Singapore: Marshall Cavendish International (Asia) Pvt. Ltd. P. 41-150.

Teoh E.S. 2016. Sources of medicianl orchids and conservation. In: Medicinal orchids of Asia. Switzerland: Springer International Publishing AG. P. 691-722.

Tsiftsis S., Tsiripidis I., Karagiannakidou V., Alifragis D. 2008. Niche analysis and conservation of the orchids of east Macedonia (NE Greece). Acta Oecologica 33(1): 27-35. DOI: $10.1016 /$ j.actao.2007.08.001

UNESCO. 2010. Central Highlands of Sri Lanka. Report of the decisions adopted by the World Heritage Committee at its $34^{\text {th }}$ session. WHC-10/34.COM/20.

Valuiskikh O.E., Teteryuk L.V. 2013. Structure and dynamics of marginal Gymnadenia conopsea (L.) R. Br. (Orchidaceae) populations on limestones in the northeast of European Russia. Russian Journal of Ecology 44(6): 461-467. DOI: 10.1134/S1067413613060106

Vilà M., Espinar J.L., Hejda M., Hulme P.E., Jarošík V., Maron J.L., Pergl J., Schaffner U., Sun Y., Pyšek P. 2011. Ecological impacts of invasive alien plants: a metaanalysis of their effects on species, communities and ecosystems. Ecology Letters 14(7): 702-708. DOI: 10.1111/j.1461-0248.2011.01628.x

Walther G., Post E., Convey P., Menzel A., Parmesan C., Beebee T.J.C., Fromentin J., Hoegh-Guldberg O., Bairlein F. 2002. Ecological responses to recent climate change. $\mathrm{Na}$ ture 416(6879): 389-395. DOI: 10.1038/416389a

Wijewardana I.H., Priyadarshana T.S., Arangala N.S., Atthanagoda A.G., Samarakoon R.T.B., Kumar P. 2016. Podochilus warnagalensis (Orchidaceae), a new species from Sri Lanka. Phytotaxa 266(2): 151-156. DOI: 10.11646/phytotaxa.266.2.10

Wijesundara S. 2012. Present status of montane forests in Sri Lanka. In: D.K. Weerakoon, S. Wijesundara (Eds.): The National Red List 2012 of Sri Lanka: Conservation Status of the Fauna and Flora. Colombo, Sri Lanka: Ministry of Environment. P. 181-185.

Xu Q., Zhang G.Q., Liu Z.J., Luo Y.B. 2014. Two new species of dendrobium (Orchidaceae: Epidendroideae) from China: Evidence from morphology and DNA. Phytotaxa 174(3): 129-143. DOI: 10.11646/phytotaxa.174.3.1

Youssef S., Galalaey A., Mahmood M., Mahdi H., Véla E. 2019. Wild orchids of the Kurdistan Region areas: a scientific window on the unexpected nature of the North-Western Zagros. France: Société Méditerranéenne d'Orchidologie. P. 1-84.

Zhang S.B., Chen W.Y., Huang J.L., Bi Y.F., Yang X.F. 2015. Orchid species richness along elevational and environmental gradients in Yunnan, China. PLoS ONE 10(11): e0142621. DOI: 10.1371/journal.pone.0142621 


\title{
ПРИОРИТЕТЫ ИССЛЕДОВАНИЙ И ПЕРСПЕКТИВЫ СОХРАНЕНИЯ ДИКОРАСТУЩИХ ОРХИДЕЙ В ШРИ-ЛАНКЕ: ОБЗОР
}

\author{
Дж. Д. Коттава-Араччи ${ }^{1, *}$, Р. С. Гунасекара ${ }^{2}$ \\ ${ }^{1}$ Институт исследования чая Шри-Ланки, Шри-Ланка \\ ${ }^{2}$ Охрана природы Шри-Ланки, Шри-Ланка \\ *e-mail: jeevan1188@yahoo.com,jeevank@tri.lk
}

Вместе с Западными Гатами Шри-Ланка является «горячей точкой биоразнообразия» среди 35 регионов, известных во всем мире. Принимая во внимание орхидеи Шри-Ланки, 70.6\% видов орхидей, включая 84\% эндемиков, классифицируются как угрожаемые. Распространение представителей семейства Orchidaceae, в основном, коррелирует с характером распределения основных биоклиматических зон, который определяется количеством и интенсивностью осадков и высотой над уровнем моря. Ухудшение и деградация среды обитания, уничтожение растительного покрова, преднамеренные лесные пожары и распространение инвазионных чужеземных видов представляют собой серьезную угрозу для аборигенных видов. Незаконный сбор и экспорт местных видов - еще одна тревожная проблема последних десятилетий. Охрана аборигенных видов, повышение осведомленности местного населения, соблюдение законодательства и внедрение новых методов размножения, несомненно, окажут благотворное влияние на флору аборигенных орхидей. Проведение информационно-просветительских программ, укрепление существующих законов и анализ правовых рамок, касающихся местной флоры орхидей, может иметь жизненно важное значение для их сохранения в будущем. Помимо выявления новых видов и их распространения, подчеркивается значимость дальнейших исследований химических и физических параметров почв в местах обитания, изучения ассоциаций растений наземных орхидей, фенологических особенностей и взаимодействий опылителей, ассоциаций с микоризой, воздействия инвазионных чужеземных видов и воздействия изменения климата.

Ключевые слова: изменение климата, исчезающие виды, незаконная эксплуатация, осведомленность, сохранение биоразнообразия 